PATTINGALLOANG

(C) Jurnal Pemikiran Pendidikan dan Penelitian Kesejarahan

\title{
Pondok Pesantren Al Urwatul Wutsqaa Kab Sidrap 1974-2018
}

Muh. Faiz', Jumadi ${ }^{2}$, Muh. Rasyid Ridha ${ }^{3}$

Prodi Pendidikan Sejarah Fakultas Ilmu Sosial UNM

'faiznurman05@gmail.com

\begin{abstract}
Abstrak
Penelitian Penelitian ini merupakan hasil penelitian yang bertujuan untuk mendeskripsikan sejarah dan perkembangan Pondok Pesantren Al Urwatul Wutsqaa di Kelurahan Benteng, Kecamatan Biranti, Kabupaten Sidrap. Metode yang digunakan adalah metode penelitian sejarah yang menjelaskan sesuatu berdasarkan perspektif sejarah. Hasil penelitian menunjukkan bahwa Pondok Pesantren Al Urwatul merupakan pondok pesantren tertua di Kabupaten Sidrap. Penelitian ini juga mengungkapkam faktor penyebab didirikannya Pondok Pesntren ini yaitu : Kurangnya sekolah berlatar belakang agama, masih kentalnya kepercayaan animisme, dan adanya cita-cita para tokoh agama dan pendidik.
\end{abstract}

Kata Kunci : Pondok Pesantren, tertua, tokoh agama, Kabupaten Sidrap.

\begin{abstract}
This research is the result of research aimed at describing the history and development of $\mathrm{Al}$ Urwatul Wutsqaa Islamic boarding school in Benteng Village, Biranti Sub-districk, Sidrap regency. The method use in the research is historical research that explain a problem based on historical perspective. The result showed that the Al Urwatul Wutsqaa Islamic boarding school is oldest boarding school in Sidrap Regency. This Study also revealed the factor causing the establishment of this islami boarding school, namely : lack of school with religious backgrounds, strong animism beliefs and ideals of religious leaders and educators.
\end{abstract}

Keywords : Islamic boarding school, the oldest, religious leader, Sidrap Regency

\section{A. Pendahuluan}

Ditinjau dari segi sejarah, belum ditemukan data yang mengungkapkan, kapan pertama kali berdirinya pesantren. Ada pendapat yang mengatakan bahwa pesantren telah ada sejak awal masuknya islam di Indonesia, sementara yang lain berpendapat bahwa pesantren baru muncul pada masa Walisongo dan Maulana Malik Ibrahim dipandang sebagai orang yang pertama mendirikan pesantren.

Pendidikan islam merupakan salah satu bidang studi islam yang mendapat banyak perhatian dari para ilmuan. Hal ini disebabkan karena di samping perananya yang amat strategis dalam rangka meningkatkan sumber daya manusia. Salah satu penelitian yang berkenaan dengan lembaga pendidikan islam adalah penelitian yang dilakukan oleh Karel A.Steenbrink dalam bukunya yang berjudul Pesantren, Madrasah dan sekolah pendidikan islam dalam kurung modern yang diterbitkan oleh LP3ES, Jakarta tahun 1982. (Nata, 2001)

Di Sulawesi Selatan terkhususnya di Kabupaten Sidrap mulai berdiri pesantren tertua pada tanggal 1 Januari 1974 yang dimana pendirinya adalah seorang ulama kharismatik di Kabupaten Sidrap yaitu KH. Abd Muin Yusuf, pesantren ini didirikan 
untuk menepati janji beliau yang ingin mendirikan pesantren di daerah kelahirannya yang diberi nama Pondok Pesantren Al Urwatul Wutsqaa. Pesantren ini didirikan untuk menampung semua golongan tanpa memprioritaskan golongan mana yang boleh masuk di pondok ini. Awal berdirinya pondok ini tidak terlalu diminati oleh sebagian pelajar yang ingin melanjutkan sekolahnya ke jenjang SMP karna menurut mereka kalau ingin belajar di sekolah agama cukup di Madrasah saja karna kalau di pesantren mereka tidak akan terlalu bebas karna adanya peraturan yang dibuat oleh pihak pesantren. Pondok Pesantren Al Urwatul Wutsqaa dari kurun tahun 1974-2018 sudah tiga kali melakukan pergantian pimpinan pesantren, pimpinan pertama sekaligus pendiri yaitu KH. Abd Muin Yusuf meletakkan pondasi pesantren, sesuai dengan namanya yang artinya tali yang kokoh dimana maknanya santri, guru dan pembina tidak akan terpecah dengan adanya masalah yang akan di hadapi, justru mereka semakin kuat dan menjadikan masalah sebagai tempat melatih ego mereka masing-masing. Pimpinan kedua adalah cucu beliau yaitu $\mathrm{H}$ Imran Muin Yusuf Lc, beliau lah yang membuat Pondok Pesantren Al Urwatul Wutsqaa punya identitas sendiri di mata masyarakat Sidrap dimana pada saat beliau menjadi pimpinan Pondok Pesantren $\mathrm{Al}$ Urwatul Wutsqaa dikenal sebagai pondok penghasil mubaliq disaat bulan suci ramadhan, santri Pondok Pesantren $\mathrm{Al}$ Urwatul Wutsqaa yang berceramah di saat bulan ramadhan sangat gampang diketahui karena cara ceramahnya sangat kental dengan ceramah bugis. (Wahidin, 2019)

Pimpinan ketiga adalah KH Asri Kasman Lc beliau adalah alumni sekaligus tenaga pengajar di Pondok Pesantren Al Urwatul Wutsqaa beliau diangkat menjadi pimpinan karna kecerdasannya, dimasa kepemimpinan beliau banyak terjadi perubahan yang dulunya di Pondok Pesantren $\mathrm{Al}$ urwatul Wutqaa tidak mempunyai sama sekali tahfidz, tapi dimasa beliau tahfidz menjadi prioritas utama dan jumlah santri yang ingin menjadi tahfidz sangat banyak walauupun tidak semuanya akan di terima menjadi tahfidz.

\section{B. Metode Penelitian}

Untuk menjawab masalah penelitian, diperlukan analisis berdasarkan metode sejarah. Sebuah metode yang merekontruksi kembali masa lampau melalui tahapan heuristik atau pengumpulan sumber-sumber sejarah, kritik, interprestasi dan historiografi. Dua jenis pengumpulan data yang digunakan dalam kajian ini yaitu penelitian lapangan dan penelitian pustaka. Penelitian pustaka dilakukan dengan metode observasi dan wawancara dengan sejumlah tokoh yang dapat memberikan keterangan mengenai pembentukan dan perkembangan Pondok Pesantren Al Urwatul Wutsqaa. Sementara penelitian pustaka dilakukan dengan mengumpulkan sumber-sumber berupa buku dan tulisan ilmiah yang mengkaji mengenai pesantren dan pendidikan islam. Sumber yang telah dikumpulkan tersebut kemudian dianalisis melalui tahapan kritik sumber, interpretasi, dan kemudian direkontruksi menjadi narasi sejarah tentang Pondok Pesantren Al Urwatul Wutsqaa di Kabupaten Sidrap.

\section{Tinjauan Penelitian}

Salah Ditinjau dari segi sejarah, belum ditemukan data yang mengungkapkan, kapan pertama kali berdirinya pesantren, ada pendapat mengatakan bahwa pesantren telah ada sejak awal masuknya islam di Indonesia, sementara yang lain berpendapat bahwa pesantren baru muncul pada masa walisongo dan maulana malik Ibrahim dipandang sebagai orang yang pertama mendirikan pesantren.

Inti dari pesantren itu adalah pendidikan ilmu agama, dan sikap beragama. Karenanya mata pelajaran yang diajarkan semata-semata pelajaran agama. Pada tingkat dasar santri baru diperkenalkan tentang dasar agama dan Al-Qur'an. Setelah berlangsung beberapa 
lama pada saat santri telah memiliki kecerdasan dari bidang tertentu. Maka mulailah diajarkan kitab kuning. Kitab kuning ini juga diklasifikasikan kepada tinkat dasar, menengah dan tinggi. Mahmud yunus membagi pesantren pada tahap-tahap itu ke empat tingkatan, yaitu: tingkat dasar,menengah,tinggi dan takhassus

\section{Hasil dan Pembahasan}

1. Sebab Berdirinya Pondok Pesantren $\mathrm{Al}$ Urwatul Wutsqaa

Di Kabupaten Sidrap sendiri, terdapat pesantren yang bernama Al Urwatul Wutsqaa yang merupakan pesantren tertua di kabupaten tersebut. Pondok Pesantren Al Urwatul Wutsqaa berdiri pada tahun 1 januari 1974. Adapun beberapa faktor yang menjadi penyebab Pondok Pesantren ini berdiri diantarannya :

a. Kurangnya sekolah yang berlatar agama Islam di Sidrap.

b. Masih kentalnya kepercayaan Animisme dan Dinamisme.

c. Adanya cita-cita para tokoh agama, tokoh masyarakat dan tenaga pendidik.

2. Proses berdirinya Pondok Pesantren AlUrwatul Wutsqaa

Setelah kembali dari Darul Falah Mekah K.H Abd Muin Yusuf tidak langsung membangun pesantren tapi justru menjadi seorang dai yang keliling Kabupaten Sidrap bahkan sampai kabuputen-kabupaten di Sulsel termasuk Pinrang, Wajo, Enrekang, Palopo, Soppeng, Pare-Pare, Barru, Makkassar, bahkan sampai luar provinsi sulsel untuk menyampaikan ajaran islam yang sudah di pelajarinya. Sambil melakukan dakwah, beliau juga mencari lokasi yang strategis untuk membangun Pondok Pesantren yang sudah lama di cita-citakannya.

Respon masyarakat terkait rencana pembangunan pesantren disambut dengan baik bahkan beberapa dari mereka menawarkan tanahnya diantaranya : a. Kelurahan Lawowoi, Kecamatan Wattang Pulu.

b. Kelurahan Amparita, Kecamatan

c. Desa Talawe Kecamatan Wattang Sidenrreng.

Dari beberapa tempat yang di tawarkan di atas beliau belum menemukan tempat yang cocok.

Pada tahun 1973 beliau bertemu dengan salah satu sahabatnya yaitu Drs Thoha Laili menawarkan sepetak tanah yang berada di depan rumahnya di Kelurahan Benteng Kabupaten Sidrap dengan alasan di kampungnya sudah banyak masyarakat melenceng dari agama islam dan berprilaku syirik (masyarakat mengkeramatkan kuburan La Pakalongi seorang Raja yang pernah memimpin di Benteng Sidrap). Hal inilah yang membuat Drs. Thoha Laili merasa bahwa pondok pesantren harus ada di sekitaran kelurahan Benteng.

Pada akhir tahun 1973 dengan bantuan tanah milik pak Thoha Laili dan bantuan Pemerintah Kabupaten Sidrap serta swadaya masyarakat kabupaten Sidrap khususnya Kelurahan Benteng Pondok Pesantren "AL Urwatul-Wutsqaa" resmi berdiri, maka citacita K.H Abd Muin Yusuf sudah terwujud yaitu mendirikan pondok pesantren. Inti dari pesantren itu adalah pendidikan ilmu agama, dan sikap beragama. (Daulay)

\section{Tokoh-Tokoh Perintis Berdirinya Pondok Pesantren Al Urwatul Wutsqaa}

Ada beberapa tokoh yang menjadi perintis berdirinya pondok ini yaitu :

a. K.H Abd Muin Yusuf

b. Drs. Thoha Laili

c. P. Lanca

Sebagai bentuk penghargaan ketiga tokoh yang berperan besar dalam proses berdirinya pesantren ini, maka ketiga tokoh ini dimakamkan di dalam kompleks pesantren. 


\section{Perkembangan Pondok Pesantren Al Urwatul Wutsqaa}

Pondok pesantren Al Urwatul Wutsqaa sampai saat ini sudah mempunyai 3 pimpinan dari awal berdirinya sampai tahun 2018 dan dibawah yayasan Abdul Muin Yusuf. Perkembangan Pondok Pesantren Al Urwatul Wutsqaa di bagi dari 3 pimpinan yang pernah memimpin di pesantren yaitu AG KH Abd Muin Yusuf selaku pendiri sekaligus pimpinan pertama yang memimpin dari tahun 1974-2002 dan di teruskan oleh cucunya yaitu H Imran Muin Yusuf Lc, Ma dari tahun 2002-2012 dan KH Asri Kasman Lc dari tahun 2012 sampai sekarang.

\section{a. AG K.H. Abd Muin Yusuf (1974-2002)}

K.H. Abdul Muin Yusuf adalah seorang sosok pemimpin bangsa dan seoaran figur ulama Sulawesi Selatan yang patut dikenang dan diteladani perjalanan hidupnya. Lahir pada tanggal 21 Mei 1920 di Rappang Kabupaten Sidrap.

Pada masa beliau menjadi pimpinan pondok pesantren, beberapa kebijakan yang diberlakukan yaitu:

1) Pondok.

Pada awal kepemimpinan K.H Abd Muin Yusuf luas pondok pesantren $\mathrm{Al}$ Urwatul Wutsqaa seluas 15X25 m dari tanah yang disumbangkan oleh Drs Thoha Laili dengan bangunan gubuk bambu dan rumah panggung sumbangan masyarakat. Adapun bangunan yang dimaksud yaitu dua bangunan gubuk dan satu bangunan rumah panggung bugis, rumah panggung bugis di tempati K.H Abd Muin Yusuf sebagai tempat tinggalnya. Beliau tinggal di atas rumah dan santri wanita tinggal di bawah rumah panggung, serta dua gubuk lainnya di tempati santri laki-laki. Di tahun ini juga beliau menawarkan tanah masyarakat di dekat pondok pesantren. Pada awal berdirinya, pesantren ini memiliki pondok yang sangat terbatas. Selain itu pada saat pendirian pondok mengalami hambatan dari salah satu partai politik yaitu Partai Golkar. Hal ini dikarenakan K.H. Abd
Mu'in Yusuf pernah menjadi penasehat Kahar Muzakkar yang bersemmbunyi di hutan pada saat pemberontakan DI/TII. Setelah itu beliau menghadap ke Bupati Sidrap yakni H. Arifin Nu,mang. Mengetahui hal tersebut $H$. Arifin Nu,mang memerintahkan kepada Camat Baranti yaitu Jalaluddin Mahyun untuk mengawal pembangunan Pondok Pesantren tersebut.

Pada tahun 1975, bupati kedua Sidrap yaitu H Arifin Nu'mang menyumbangkan bangunan permanen asrama dengan lima kamar. Bantuan tersebut diberikan terdahulu ke Bupati Sidrap dan setelahnya bantuan tersebut langsung diberikan ke pimpinan pondok. (Assad, 2019) Dengan adanya tambahan bangunan ini, membuat sarana dalam Pondok Pesantren bertambah dan lebih layak.

Adapun jumlah rincian bangunan di akhir kepemimpinan K.H. Abd Muin Yusuf adalah

(a) 40 kamar dengan bangunan permanen 25 kamar untuk laki-laki dan 15 kamar untuk perempuan .

(b) bangunan ruang belajar terdapat 11 kelas ruangan belajar 3 kelas untuk MA dan 8 kelas untuk Mts bangunan masjid depan pondok pesantren masih di gunakan untuk belajar

(c) 4 sumur

(d) $4 \mathrm{WC}$

2) Masjid.

Masjid yang di tempati para santri, guru dan pembina untuk melakukan ibadah shalat lima waktu dan shalat jum'at adalah masjid yang berada di depan Pondok Pesantren. Adapun nama masjid tersebut yaitu masjid Nurul Hidayah yang terletak di samping rumah Drs Thoha Laili, selain berfungsi sebagai tempat ibadah masjid ini juga difungsikan sebagai tempat belajar

3) Pengajian kitab islam klasik.

Pengajian kitab islam klasik sering dilaksanakan di Pondok Pesantren Al Urwatul Wutsqaa dimana pada waktu selesai shalat Shubuh, K.H Abd Muin Yusuf 
sendirilah yang membawakan pengajian tersebut dan dimana tidak hanya santri saja yang mengikuti pengajian tersebut tapi masyarakat sekitar pun juga ikut dalam pengajian kitab klasik yang dibawakan oleh K.H Abd Muin Yusuf

4) Santri.

Santri pada tahun awal berdirinya Pondok Pesantren Al Urwatul Wutsqaa yaitu pada tahun 1974 adalah sebagai berikut :

(a) Angkatan pertama berjumlah 20 santri.

(b) Angkatan kedua berjumlah 29 santri.

(c) Angkatan ketiga berjumlah 31 santri

(d) 24 santri Alumni angkatan keempat

(e) 26 santri alumni angkatan ke lima

Kebanyakan santri melanjutkan studi di Al Azhar Kairo. Salah satu kelebihan dalam pengiriman santri ke Al Azhar Kairo adalah proses seleksi yang tidak dikenakan kepada santri, mereka hanya menunjukkan tanda tangan K.H Abd Muin Yusuf sebagai bukti rekomendasi ke Kedutaan Besar Republik Indonesia (KBRI) di Mesir.

5) Kyai.

Kyai pada waktu itu adalah K.H Abd Muin Yusuf selaku pimpinan pondok beliau sangat di hormati oleh santri, guru, pembina dan masyarakat sekitar. Selain kyai ada juga beberapa guru yang membantu beliau dalam mengurusi pesantren salah satunya adalah bapak Drs Muhammad assad, bisa di bilang beliau ini adalah orang kepercayaan K.H Abd Muin Yusuf dalam membangun pesantren.Selain itu K.H Abd Muin Yusuf selalu mengirim santrinya di setiap angkatan ke mesir untuk melanjutkan studi agama di Al Azhar Kairo. Di lima tahun kepemimpinan K.H. Abd Muin Yusuf tercatat sudah ada 150 santri yang pernah mondok di Pondok Pesantren Al Urwatul Wutsqaa dengan guru sebanyak 20an orang diantaranya pak Thoha Laili (guru fisika) Muhammad Assad (guru Olahraga) Mahmud (guru ngaji)

Seiring bertambahnya usia, beliau mulai sakit-sakitan. K.H. Abdul Muin Yusuf wafat pada tanggal 23 juni 2004 dalam usia 84 tahun dan dikebumikan dalam kompleks pesantren yang di bangunnya yaitu Pondok Pesantren Al Urwatul Wutsqaa di Kelurahan Benteng, Kec Baranti, Kab Sidrap.

\section{b. K.H. Imran Muin Yusuf Kuba Lc. M.HiK.H}

Imran Muin Yusuf Kuba adalah cucu langsung dari K.H Abd Muin Yusufyang merupakan pendiri pondok pesantren $\mathrm{Al}$ Urwatul Wutsqaa.Beliau merupakan anak dari Anwar Kuba dan $\mathrm{Hj}$. Fauziyah Muin. Beliau lahir di Rappang 6 juni 1970.

Pada masa beliau menjadi pimpinan pondok pesantren, beberapa kebijakan diberlakukan yaitu:

1) Pondok

Pada tahun 2002 awal kepemimpinan H. Imran Muin asrama santri perempuan yang dulunya berada dibagian depan di pindahkan ke bagian belakang, beliau juga masih mempertahankan aturan-aturan pimpinan terdahulu.

Adapun rincian bangunan pada masa kepemimpinan beliau adalah penambahan 1 masjid, 1 musollah, 1 Koperasi, 10 ruangan kelas, 10 kamar santri wati dan 10 kamar santri wan. Tetapi rumah panggung dan gubuk bamboo sudah tidak ada pada zaman beliau memimpin.

2) Masjid

Pada tahun 2002 sampai 2008 masjid depan pesantren yaitu masjid yang di gunakan santri pada awal berdirinya pesantren, pada akhir tahun 2008 santri hanya bisa shalat jum'at di masjid depan pesantren dan shalat lima waktu dilakukan di Musollah Al Muin, sedangkan santri perempuan melakukan shalat lima waktu di masjid syuhada 45 dimana masjid ini di bangun pada awal kepemimpinan H. Imran

3) Pengajian kitab islam klasik.

Pada awal kepemimpinan beliau pengajian kitab kuning masih sering dilakukan setiap selesai shalat subuh, tetapi pada waktu pindahnya santri melaksanakan shalat lima waktu di musollah Al Muin, 
pengajian kitab kuning sudah tidak rutin. Pada tahun 2009 banyak santri yang punya minat belajar kitab kuning di kirim ke pambusuang Kabupaten Polewali untuk melanjutkan pengajian kitab kuning, tetapi pada akhir masa kepemimpinannya beliau melanjutkan kembali melakukan rutinitas belajar kitab kuning dikarenakan beberapa alumni pondok pesantren yang sudah belajar di Al Azhar, Kairo, Mesir sudah kembali ke tanah air.

4) Santri

Penerimaan santri pada awal kepemimpinan beliau cukup mudah yaitu santri hanya di test bacaan Al-Qur'an. Tetapi pada tahun 2006 selain test bacaan $\mathrm{Al}$-Qur'an santri sudah di test tertulis.. Pada tahun 2006 terdapat satu kemunduran di bidang pendidikan dimana hanya dua santri yang lolos ke Kairo yaitu Andi Rahman Rukman dan Anugrah Hardin. Setelah itu tidak ada lagi santri yang melanjutkan pendidikan ke kairo mesir sampai periode kepemimpinan H Imran Muin Yusuf.

Selain itu, santri pada waktu itu dibebaskan untuk menentukan apa minat olahraga yang di inginkan dan pada waktu itu ada dua olahraga bela diri di pesantren yaitu Shorinji Kempo dan Karate prestasi di dua bidang olahraga bela diri ini sangat membanggakan khususnya di bidang Shorinji Kempo.

5. Kyai

K.H Imran Muin Anwar Kuba Lc. M.Hi selaku pimpinan adalah salah satu kyai yang berada di Pondok Pesantren beliau dibantu oleh beberapa kyai yang pernah mondok di Pondok Pesantren Al Urwatul Wutsqaa yang di antaranya adalah K.H Lakalebbi S.Ag, K.H Muh Asri Kasman Lc, K.H Burhanuddin Lc. Adapun jumlah guru pada waktu beliau sebanyak 30 .

Seiring berjalannya waktu pada akhir tahun 2012 K.H Imran Muin Yusuf mengundurkan diri sebagai pimpinan sekaligus ketua yayasan di pondok pesantren Al Urwatul Wutsqaa di karenakan beliau ingin melanjutkan pendidikan doktor di UIN Alauddin Makassar. (Kuba, 2019)

\section{c. K.H Muh Asri Kasman Lc}

K.H Asri Kasman lahir dan besar di Kadidi pada 22 Mei 1962. Beliau adalah putra dari H. Muh Kasau dan Hj. Manca, beliau adalah anak ketiga dari tujuh bersaudara, beliau pernah menjadi santri dan angkatan ke tiga di Pondok Pesantren Al Urwatul Wutsqaa. Setelah itu beliau melanjutkan pendidikan Program Sarjananya di Al Azhar, Kairo, Mesir dengan mengambil jurusan perbandingan agama. (M.Hum, 2019)

Pada akhir tahun 2012 terjadi kekosongan pimpinan di Pondok Pesantren Al Urwatul Wutsqaa. Ketua yayasan pesantren pada waktu itu adalah H. Surkati Muin yang mengantikan K.H Imran Muin Yusuf. Setelah melalui banyak pertimbangan dipilihlah K.H Muh Asri Kasman Lc sebagai pimpinan dikarenakan beliau lebih paham dan siap dibandingkan senior-seniornya. (Assad D. H., 2019)

1) Pondok

Rincian bangunan pada masa kepemimpinan K.H Asri Kasman adalah masjid baru di kawasan santri wati yaitu masjid syuhada 45 , asrama bertingkat untuk santri san dan santri wati, banguna kelas berjumlah 10 kelas, asrama rumah panggung bugis berjumlah 4 yang di gunakan untuk santri tahfidz dan santri khusus berbahasa asing. Prasarana di bagian olahraga juga banyak di adakan yaitu pengadaaan lapangan sepak bola, tennis meja, renovasi lapangan futsal, volli, sepak takraw, lapangan kempo.

2) Masjid

Tempat ibadah yang di pakai shalat lima waktu saat itu masih mushollah Al Muin untuk santri laki-laki sedangkan untuk shalat jum'at yang dulunya santri melakukannya di masjid depan pesantren kini pindah ke masjid syuhada 45 yang dimana masjid itu sudah dibangun ulang dan di pindahkan ke timur masjid sebelumnya, sedangkan 
bangunan masjid yang lama digunakan sebagai tempat olaharaga tennis meja.

3) Pengajian kitab islam klasik

Pada awal kepemimpinan K.H Muh Asri Kasman pengajian kitab kuning dari periode sebelumnya dilanjutkan. Hal yang berbeda adalah konsep hanya santri yang sudah berada pada tingkatan Madrasah Aliyah wajib mengikuti program ini, yang dilakukan pada setiap hari selesai waktu subuh.

4) Santri

Penerimaan santri pada tahun 2013 dan 2014 dimasa beliau melalui beberapa test yaitu dengan test baca $\mathrm{Al}$ Qur'an, test tulis, test keterampilan, tets bacaan shalat dan test wudhu. Dapat dikatakan bahwa pada periode ini anak yang diterima menjadi santri adalah mereka yang punya kecerdasaan dan bukan lagi anak-anak yang nakal.

5) Kyai

Kyai pada waktu itu adalah beliau selaku pimpinan didalam menjalankan roda kepemimpinan Pondok Pesantren Al Urwatul Wutsqaa beliau dibantu oleh K.H Lakalebbi S.Ag, selaku wakil pimpinan, K.H Burhanuddin Lc. Selaku bendahara pimpinan dan beberapa guru yang tamatan Al Azhar Kairo Mesir serta lulusan kampuskampus negeri yang berbasis islam di Indonesia.. Jumlah guru pada waktu itu masih dengan guru yang sama di tambah beberapa guru baru yaitu; Ahira, Sofyan, Asma Asha, Radiyah, Soeharto,Sultan Buana.

\section{Dampak Kehadiran Pondok Pesantren Al Urwatul Wustaqaa}

\section{a. Dampak Keagamaan}

Dengan adanya pondok pesantren $\mathrm{Al}$ Urwatul Wutsqaa dampak keagamaan di sekitar wilayah Kabupaten Sidrap dan sekitarnya terkhusus di Kelurahan Benteng mengalami perubahan. Perubahan dapat dilihat dari dulunya masjid yang berada di depan pondok pesantren sangat sepi dalam menjalankan ibadah shalat lima waktu, akan tetapi dalam kurung waktu empat puluh tahun masjid ini sudah ramai dalam kegiatan shalat lima di buktikan dengan renovasi masjid yang sudah dilakukan dua kali karena masjid sudah tidak bisa menampung orang didalamnya

\section{b. Dampak Pendidikan}

Dampak pendidikan dengan adanya Pondok Pesantren Al Urwatul Wutsqaa di masyarakat adalah,dimana pada waktu itu akses pendidikan tingkat SMP dan SMA yang berada jauh di bagian Rappang, pondok pesantren $\mathrm{Al}$ Urwatul Wutsqaa hadir untuk mempermudah akses pendidikan masyarakat di Kelurahan Benteng dan sekitarnya ketika tamat di sekolah dasar. Dampak pendidikan yang lain di dapat ketika sudah berstatus santri dimana santri yang dulunya nakal masuk di Pondok Pesantren Al Urwatul Wutsqaa ketika selesai mondok kebanyakan dari mereka punya etika yang sangat baik. Adapun ilmu yang juga di dapat dari mondok selain pelajaran umum yang biasa di dapat pada sekolah-sekolah negeri adanya beberapa pelajaran agama.

Selain itu santri juga di ajarkan kitab islam klasik atau biasa dikenal dengan kitab kuning serta adanya rumah tahfidz dan rumah bahasa membuat pendidikan santri bisa memilih mana yang bagus di dalaminya.

\section{c. Dampak Sosial}

Keberadaan Pondok Pesantren dalam suatu masyarakat merupakan kebanggan tersendiri ketika pondok pesantren tersebut dapat beradaptasi dengan masyarakat setempat. Sehingga tercipta hubungan baik antara masyarakat dan Pondok Pesantren. Pondok Pesantren Al Urwatul Wutsqaa ini sangat mementingkan atau sangat menghormati masyarakat Kelurahan Benteng karena penting sekali menanamkan nilai menghargai dan kepandaian menempatkan diri dalam jiwa seorang santri, karena disadari atau tidak hubungan keluar dengan masyarakat itu adalah suatu kepastian, sebesar apapun Pondok Pesantren itu, 
masyarakat adalah struktur yang tidak mungkin ditinggalkan dalam sejarahnya.

Aktifitas sosial memiliki pengaruhbesar bagi kelangsungan hidup masyarakat, karena pada dasarnya dalam hidup bermasyarakat perlu adanya keseimbangan baik kehidupan sosial maupun moral serta tidak lupa diimbangi dengan keimanan yang tinggi terjalin Ukhuwah Islamiyah yang kokoh. Kehadiran Pondok Pesantren Al Urwatul Wutsqaa ikut mewarnai kehidupan sosial masyarakat benteng. Adanya beberapa program sosial yang disuguhkan oleh lembaga pondok, dapat berdampak positif bagi masyarakat terutama yang tinggal disekitaran lingkungan Pondok Pesantren Al Urwatul Wutsqaa.

Hubungan Pondok Pesantren dengan masyarakat merupakan salah satu sarana untuk mengamalkan ajaran agama islam, kegiatan sosial yang dilakukan oleh pondok pesantren ini selalu mengalami peningkatan dari tahun ketahun. Kegiatan kemasyarakatan ini ada yang dilakukan setiap satu tahun sekali dan ada setiap bulan sekali. Kegiatan ini terus mengalami keamajuan setiap tahunnya, secara tidak langsung pondok pesantren telah berdakwah melalui kegiatan kemasyarakatan. (Inarwati, I., Najamuddin, N., \& Ridha, M. R., 2018)

Kerukunan dan ketertiban adalah syarat utama bagi sehatnya pergaulan sosial. Seperti yang dikatakan salah satu Pembina Pondok Pesantren Al Urwatul Wutsqaa. (Ar-raffany, 2019) Ketika seseorang hidup di lingkungan pondok atau lebih di kenal dengan santri, maka harus menciptakan kerukunan dan ketertiban dalam pondok. Karena kerukunan dan ketertiban itulah yang akan terciptanya pergaulan santri satu dengan yang lainnya. Hal tersebut sebagai syarat pergaulan sosial terutama di pondok pesantren. (Hum, 2019)

Dampak secara langsung, adanya Pondok Pesantren Al Urwatul Wutsqaa ini memusatkan perbaikan moral para santri melalui kitab-kitab yang diajarkannya. Santri di pondok pesantren tidak serta merta menciptakan rasa kebersamaan dan kerukunan terhadap sesama. Santri di pondok pesantren akan di gembleng dan diajak pada perbaikan moral melalui kitabkitab yang di ajarkan kyai. Dengan hal ini santri dapat menyerap atau memahami secara langsung setelah apa yang diajarkan oleh kyai dan akan menjadikannya perubahan moral setiap individu untuk bekal suatu saat nanti ketika sudah lulus di Pesantren.

\section{E. Kesimpulan}

Dari pembahasan terkait Pondok Pesantren Al Urwatul Wutsqaa dapat ditarik kesimpulan sebagai berikut :

1. Kabupaten Sidrap terdapat Pondok Pesantren Al Urwatul Wutsqaa berdiri pada tahun 1 januari 1974. Adapun latar belakang berdirinya pesantren tersebut adalah:

2. Kurangnya sekolah yang berlatar agama Islam di Sidrap.

3. Masih kentalnya kepercayaan Animisme dan Dinamisme.

4. Adanya cita-cita para tokoh agama, tokoh masyarakat dan tenaga pendidik.

Pondok Pesantren Al Urwatul Wutsqaa sampai saat ini sudah mempunyai 3 pimpinan dari awal berdirinya sampai tahun 2018 dan dibawah yayasan Abdul Muin Yusuf. Dampak yang ditimbulkan dengan hadirnya pesantren ini antara lain; Perubahan dapat dilihat dari dulunya masjid yang berada di depan pondok pesantren sangat sepi dalam menjalankan ibadah shalat lima waktu, akan tetapi dalam kurung waktu empat puluh tahun masjid ini sudah ramai dalam kegiatan shalat lima di buktikan dengan renovasi masjid yang sudah dilakukan dua kali karena masjid sudah tidak bisa menampung orang didalamnya, kemudian berstatus santri dimana santri yang dulunya nakal masuk di Pondok Pesantren Al Urwatul Wutsqaa ketika selesai mondok kebanyakan dari mereka punya etika yang sangat baik, dan Kehadiran Pondok Pesantren Al Urwatul 
Wutsqaa ikut mewarnai kehidupan sosial masyarakat benteng.

\section{DAFTAR PUSTAKA}

Ar-raffany, U. W. (2019, agustus 10). Dampak Sosial Pondok Pesantren Al Urwatul Utsqaa.

Assad, D. H. (2019, Mei 4).

Assad, D. H. (2019, Mei 4). Pondok Pesantren Al Urwatul Wutsqaa masa pemerintahan K. H. Muh Asri Kasman Lc.

Daulay, P. D. Sejarah Pertumbuhan dan Pembaharuan Pendidikan Islam di Indonesia. Jakarta: Kencana Prenada Media Group.

Hum, D. H. (2019, Mei 2019). Dampak Sosial Pondok Pesantren Al Urwatul Utsqaa.

Kuba, H. I. (2019, Mei 8). Pondok Pesantren Al Urwatul Wutsqaa masa pemerintahan K. H. Imran Muin Yusuf Lc. M.H.I.

Inarwati, I., Najamuddin, N., \& Ridha, M. R. (2018). Pesantren Sultan Hasanuddin Kecamatan Bajeng Kabupaten Gowa Tahun 1986-2017. Jurnal Pattingalloang, 5(3), 112-122.

M.Hum, D. H. (2019, Mei 8). Pondok

Pesantren Al Urwatul Wutsqaa masa pemerintahan K. H. Muh Asri Kasman Lc.

Nata, A. (2001). Metodologi Studi Islam. Jakarta: Grafindo Persada.

Wahidin, U. (2019, Agustus 10). Pondok Pesantren Al Urwatul Wutsqaa. 